Journal of Clinical Investigation

Vol. 42, No. 7, 1963

\title{
METABOLIC CHANGES IN NORMAL AND GLUCOSE-6-PHOSPHATE DEHYDROGENASE-DEFICIENT ERYTHROCYTES INDUCED BY ACETYLPHENYLHYDRAZINE *
}

\author{
By NECHAMA STERNSCHUSS KOSOWER, GRACE A. VANDERHOFF, \\ ERNST R. JAFFÉ, $\dagger$ AND IRVING M. LONDON
}

\author{
(From the Department of Medicine, Albert Einstein College of Medicine and the Bronx \\ Municipal Hospital Center, New York, N. Y.)
}

(Submitted for publication December 20, 1962; accepted February 28, 1963)

In studies on the mechanisms of hemolysis in mammalian erythrocytes, the role of the metabolism of the erythrocyte in the maintenance of the structural integrity of the cell has been increasingly appreciated. Detailed knowledge of the chemical and physical events that occur in various kinds of hemolysis is not yet available, however. The discovery of a genetically determined deficiency in the activity of glucose-6-phosphate dehydrogenase (G6PD) in the erythrocytes of certain individuals who experience hemolytic reactions upon exposure to various chemical agents (2) has provided opportunities for detailed study of some aspects of hemolysis. The life span of these enzymedeficient erythrocytes is normal (3) or only slightly shortened (4) in the absence of exposure to hemolytic substances. Obvious hemolysis does occur, however, when the subject is exposed to the fava bean, primaquine, and certain other chemicals. The deficiency in G6PD activity results in diminished regeneration of $\mathrm{TPNH}$, which is required for the conversion of GSSG to GSH (5). After the administration of primaquine to sensitive individuals, a marked decrease in erythrocyte GSH occurs just prior to the major hemolytic episode (6). A rapid and marked decline in the content of GSH can be produced in vitro upon incubation of deficient cells with a compound such as acetylphenylhydrazine (APH) (7).

The studies that are described in the present report were designed to provide more information

* An abstract, presenting part of this work, has been published (1). This investigation was supported by grant H-2803 from the National Institutes of Health, U. S. Public Health Service, and grant AT(30-1) 1855 from the Atomic Energy Commission.

$\dagger$ Recipient of an investigatorship of the Health Research Council of the City of New York under contract no. I-169. about the metabolic changes that occur in G6PDdeficient erythrocytes when they are exposed to $\mathrm{APH}$ and when the concentration of GSH in these erythrocytes is markedly diminished. Such information might help to determine whether the diminution in the concentration of GSH is correlated with other metabolic changes that might lead to enhanced susceptibility of the erythrocytes to hemolysis. Attention was directed to the effects of treatment with APH on glycolysis, the principal mechanism for the production of energy in the mature mammalian erythrocyte, and on the activities of certain of the enzymes in the glycolytic pathway that might be especially sensitive to the action of such compounds.

\section{METHODS}

A. Incubation. Blood was obtained from normal individuals and from adult Negro male subjects whose erythrocytes were found to be deficient in G6PD activity as determined by the method of Kornberg and Horecker, modified by Marks (8). The blood, anticoagulated with $1 \mathrm{mg}$ of heparin per $10 \mathrm{ml}$ of blood, was centrifuged, and after the plasma and buffy coat were removed, the cells were washed twice with $0.9 \%$ sodium chloride solution. The centrifugation and washing procedures were carried out at $4^{\circ} \mathrm{C}$. Cell suspensions of $70 \%$ were prepared in isotonic sodium phosphate buffer, $\mathrm{pH} 7.3$, containing glucose, penicillin, and streptomycin. To samples of these suspensions, equal volumes of phosphate buffer alone or phosphate buffer containing APH, $5.0 \mathrm{mg}$ per $\mathrm{ml}$, were added. The final concentrations in the incubation mixtures were as follows: volume of packed red cells, $35 \%$; glucose, $2.0 \mathrm{mg}$ per $\mathrm{ml}$; penicillin, $0.1 \mathrm{mg}$ per $\mathrm{ml}$; streptomycin, $0.1 \mathrm{mg}$ per $\mathrm{ml}$; and $\mathrm{APH}$, $2.5 \mathrm{mg}$ per $\mathrm{ml}$. The samples were incubated in air in a Dubnoff metabolic shaker-incubator at $37^{\circ} \mathrm{C}$ for $7 \frac{1}{2}$ hours. Samples of the incubation mixture were removed at $0,2 \frac{1}{2}, 5$, and $7 \frac{1}{2}$ hours for the various assays.

B. Assays. Lactic acid (LA) and pyruvic acid (PA) were determined by the methods of Barker and Summerson (9) and Friedemann and Haugen (10), respec- 
tively. One $\mathrm{ml}$ of incubation mixture and $6 \mathrm{ml}$ of cold $2 \%$ perchloric acid were mixed, and the clear filtrates were used for the assays. Glucose was determined by the method of Nelson (11). Reduced glutathione was determined in metaphosphoric acid extracts of samples of the incubation mixtures by the method of Beutler (7). The quantities of LA, PA, glucose, and GSH in the incubation mixtures were related to the volume of packed erythrocytes that was determined by the method of Wintrobe (12). The values for production of LA and PA and for utilization of glucose during the period of incubation were derived from the differences between the amounts measured at the beginning and at the end of the incubation.

Glyceraldehyde-3-phosphate dehydrogenase (GA3PD) was measured in a lysate that was prepared by adding a sample of the incubation mixture to 3 vol of a solution of $0.01 \mathrm{M}$ EDTA and $3.3 \times 10^{-4} \mathrm{M}$ DPN at $\mathrm{pH}$ 7.4. This lysate was diluted 20 times with $0.01 \mathrm{M}$ EDTA, $\mathrm{pH} 7.4$, immediately before use in the enzyme assay. The amount of lysate used in the assay contained from 0.03 to $0.09 \mathrm{mg}$ hemoglobin. The assay was performed according to the method of $\mathrm{Wu}$ and Racker (13), by use of the backward reaction.

Lactic acid dehydrogenase (LDH) was assayed as follows. A sample of the incubation mixture was added to 3 vol of distilled water, and the resulting lysate was further diluted 20 times with water just prior to use in the assay. The assay was performed according to the method of Wróblewski and LaDue (14) with slight modifications. A total volume of $1.0 \mathrm{ml}$ contained $56 \mu \mathrm{g}$ of PA, $120 \mu \mathrm{g}$ of DPNH, and lysate containing from 0.05 to 0.1 $\mathrm{mg}$ hemoglobin. The assay was performed at $\mathrm{pH} 7.4$ with a final concentration of $4.4 \times 10^{-2} \mathrm{M}$ sodium phosphate buffer. Under these conditions, the amount of PA was optimal for the enzyme activity in the lysate.

A unit of activity of either GA3PD or LDH was defined as the amount of enzyme required to produce a

TABLE I

Concentrations of GSH and production of lactic acid $(L A)$ and pyruvic acid $(P A)$ in normal and glucose-6-phosphate dehydrogenase (G6PD)-deficient erythrocytes incubated for $7 \frac{1}{2}$ hours with glucose in the absence and presence of added acetylphenylhydrazine $(A P H)$

\begin{tabular}{|c|c|c|c|c|c|c|c|c|}
\hline \multirow[b]{3}{*}{ Subject } & \multirow{2}{*}{\multicolumn{2}{|c|}{ Lactic acid }} & \multirow{2}{*}{\multicolumn{2}{|c|}{ Pyruvic acid }} & \multicolumn{2}{|c|}{ Ratios } & \multirow{2}{*}{\multicolumn{2}{|c|}{ GSH }} \\
\hline & & & & & \multirow{2}{*}{$\begin{array}{l}\text { LA (APH): } \\
\text { LA (Control) }\end{array}$} & \multirow{2}{*}{$\begin{array}{l}\mathrm{LA}+\mathrm{PA}(\mathrm{APH}): \\
\mathrm{LA}+\mathrm{PA} \text { (control) }\end{array}$} & & \\
\hline & Control & $\mathrm{APH}$ & Control & $\mathrm{APH}$ & & & Control & APH \\
\hline Normol & \multicolumn{2}{|c|}{$\begin{array}{c}\text { umoles } / 100 \mathrm{ml} \\
\text { erythrocytes }\end{array}$} & \multicolumn{2}{|c|}{$\begin{array}{c}\text { Amoles } / 100 \mathrm{ml} \\
\text { erythrocytes }\end{array}$} & & & \multicolumn{2}{|c|}{$\begin{array}{l}\mathrm{mg} / 100 \mathrm{ml} \\
\text { erythrocytes }\end{array}$} \\
\hline E.G. & 3,161 & 2,821 & & & .89 & & 47 & 27 \\
\hline M.K.W. & 2,741 & 2,458 & & & .90 & & 63 & 32 \\
\hline \multirow[t]{2}{*}{ G.V. } & 2,703 & 2,287 & $\mathbf{0}$ & 364 & .85 & .98 & 82 & 40 \\
\hline & 2,789 & 2,585 & 0 & 382 & .93 & 1.06 & 71 & 53 \\
\hline N.S. & 2,211 & 2,156 & $\mathbf{0}$ & 352 & .98 & 1.13 & 70 & 39 \\
\hline \multirow{3}{*}{ E.R.J. } & 2,460 & 2,242 & $\mathbf{0}$ & 309 & .91 & 1.04 & 87 & 51 \\
\hline & 3,011 & 2,584 & $\mathbf{0}$ & 416 & .86 & 1.00 & 81 & 42 \\
\hline & 2,763 & 2,440 & 0 & 390 & .88 & 1.02 & & \\
\hline B.A.L. & 2,529 & 2,501 & 31 & 349 & .99 & 1.11 & 65 & 31 \\
\hline J.L.C. & 3,074 & 2,810 & 8 & 310 & .91 & 1.01 & 75 & 51 \\
\hline L.G. & 2,792 & 2,557 & 0 & 397 & .92 & 1.06 & 65 & 22 \\
\hline McG. & 3,106 & 2,661 & 55 & 639 & .88 & 1.02 & 77 & 37 \\
\hline G.N. & 2,731 & 2,667 & 55 & 386 & .98 & 1.10 & 68 & 41 \\
\hline Mean $\pm \mathrm{SE}$ & $2,775 \pm 76$ & $2,521 \pm 57$ & & $390 \pm 27$ & $.91 \pm .013$ & $1.05 \pm .015$ & $71 \pm 3.1$ & $39 \pm 2.8$ \\
\hline Comparison & \multicolumn{2}{|c|}{$\mathrm{p}<.02$} & & & & & & \\
\hline \multicolumn{9}{|l|}{$\begin{array}{l}\text { G6PD- } \\
\text { deficient }\end{array}$} \\
\hline \multirow[t]{4}{*}{ L.G. } & 2,930 & 1,758 & & & .60 & & 40 & 3 \\
\hline & 3,488 & 2,059 & 0 & 443 & .59 & .72 & 42 & 1. \\
\hline & 2,649 & 1,650 & $\mathbf{0}$ & 489 & .62 & .81 & 46 & 3 \\
\hline & 3,083 & 1,563 & 10 & 547 & .51 & .68 & 57 & $\mathbf{0}$ \\
\hline E.S. & 2,573 & 1,674 & & & .65 & & 41 & 5 \\
\hline B.L. & 2,444 & 1,172 & & & .48 & & 38 & 0 \\
\hline \multirow{3}{*}{ A.M. } & 3,258 & 2,062 & 0 & 568 & .63 & .81 & 55 & 0 \\
\hline & 4,250 & 2,781 & 0 & 670 & .65 & .81 & & \\
\hline & 3,223 & 1,860 & 11 & 559 & .58 & .75 & 71 & 5 \\
\hline J.H. & 3,157 & 2,198 & 0 & 451 & .70 & .84 & 52 & 3 \\
\hline A.T. & 2,879 & 1,991 & 7 & 401 & .69 & .83 & 54 & $\mathbf{0}$ \\
\hline P.J. & 3,111 & 2,059 & 68 & 773 & .62 & .89 & 51 & 4 \\
\hline C.W. & 3,434 & 2,034 & 9 & 507 & .59 & .74 & 48 & 0 \\
\hline Mean $\pm \mathrm{SE}$ & $3,114 \pm 130$ & $1,912 \pm 106$ & & $541 \pm 35$ & $.61 \pm .017$ & $.79 \pm .02$ & $50 \pm 2.7$ & $2 \pm 0.6$ \\
\hline Comparison & \multicolumn{2}{|c|}{$\mathrm{p}<.001$} & & & & & & \\
\hline $\begin{array}{c}\text { Comparison, } \\
\text { normal vs. } \\
\text { deficient }\end{array}$ & $\mathrm{p}<.05$ & $\mathrm{p}<.001$ & & $\mathrm{p}<.01$ & & & & \\
\hline
\end{tabular}


decrease in optical density (OD) at $340 \mathrm{~m} \mu$ of 1,000 per minute per gram of hemoglobin.

Hemoglobin determinations on the lysates used in the enzyme assays were performed by the cyanmethemoglobin method of Crosby, Munn, and Furth (15).

\section{RESULTS}

Effects of APH treatment on glycolysis. Table I presents data obtained from experiments in which normal and G6PD-deficient erythrocytes were incubated for $7 \frac{1}{2}$ hours with glucose in the absence and in the presence of added APH. The findings may be summarized as follows. a) In the absence of APH, there was little or no accumulation of PA in either the normal or G6PD-deficient cells. b) On incubation of normal cells with APH, there was a decline in the formation of LA and an equivalent rise in the accumulation of PA. As a result, the ratio of the sum of LA plus $P A$ in the presence of APH to the sum of LA plus PA in its absence approximated one. c) In G6PD-deficient cells, treatment with $\mathrm{APH}$ resulted in a greater decline in LA and a greater rise in PA than were observed in normal cells. The increased accumulation of $\mathrm{PA}$, however, did not fully compensate for the marked diminution of LA, and the ratio of the sum of LA plus PA with APH to the sum of LA plus PA without APH was approximately 0.8. d) These findings were observed under con-

TABLE II

Utilization of glucose by normal and glucose-6-phosphate dehydrogenase $(G 6 P D)$-deficient erythrocytes after preincubation in the absence and presence of added acetylphenylhydrazine $(A P H)^{*}$

\begin{tabular}{lcccc}
\hline \hline & \multicolumn{2}{c}{$\begin{array}{c}\text { Glucose utilized } \\
\text { in 2 hours }\end{array}$} & & Ratio \\
\cline { 2 - 3 } Erythrocytes & Control & $\begin{array}{c}\text { APH- } \\
\text { treated }\end{array}$ & & $\begin{array}{c}\text { APH-treated: } \\
\text { Control }\end{array}$ \\
\hline & $\begin{array}{c}\mu g / m l \\
\text { erythro- } \\
\text { cytes }\end{array}$ & $\begin{array}{c}\mu g / m l \\
\text { erythro- } \\
\text { cytes }\end{array}$ & \\
Normal & 617 & 476 & \\
E.R.J. & 777 & 658 & .77 \\
J.L.C. & 536 & 438 & .85 \\
M.V. & & & .82 \\
G6PD-deficient & 781 & 373 & \\
P.J. & 567 & 368 & .48 \\
M.E. & 510 & 230 & .65 \\
J.H. & & & .45 \\
\hline
\end{tabular}

* Preincubation: Washed erythrocytes were incubated for 5 hours in phosphate buffer, pH 7.3 , with glucose, $200 \mathrm{mg}$ per $100 \mathrm{ml}$ in the presThe cells were then washed three times with phosphate buffer, $\mathrm{pH} 7.3$ The cells were then washed three times with phosphate buffer, $\mathrm{pH} 7.3$. and incubated for 2 hours with added glucose, $50 \mathrm{mg}$ per $100 \mathrm{ml}$. hours of incubation.
TABLE III

Effects of incubation with acetylphenylhydrazine $(A P H)$ on GSH content and on activity of glyceraldehyde-3-phosphate dehydrogenase $(G A 3 P D)$ of normal and glucose- 6 -phosphate dehydrogenase (G6PD)-deficient erythrocytes

\begin{tabular}{|c|c|c|c|c|c|}
\hline \multirow[b]{2}{*}{ Subject } & & \multicolumn{2}{|c|}{ GSH } & \multicolumn{2}{|c|}{$\begin{array}{l}\text { GA3PD } \\
\text { activity }\end{array}$} \\
\hline & & $0 \mathrm{hr}$ & $7 \frac{1}{2} \mathrm{hrs}$ & $0 \mathrm{hr}$ & $7 \frac{1}{2} \mathrm{hrs}$ \\
\hline Normal & & \multicolumn{2}{|c|}{$\begin{array}{l}m g / 100 \mathrm{ml} \\
\text { erythrocytes }\end{array}$} & \multicolumn{2}{|c|}{$\begin{array}{l}\text { OD, } U / \min / g \\
\text { of hemoglobin }\end{array}$} \\
\hline E.J. & $\begin{array}{l}\text { Control } \\
\text { APH }\end{array}$ & $\begin{array}{l}69 \\
67\end{array}$ & $\begin{array}{l}68 \\
32\end{array}$ & $\begin{array}{l}627 \\
571\end{array}$ & $\begin{array}{l}683 \\
633\end{array}$ \\
\hline G.V. & $\begin{array}{l}\text { Control } \\
\text { APH }\end{array}$ & $\begin{array}{l}82 \\
72\end{array}$ & $\begin{array}{l}82 \\
40\end{array}$ & $\begin{array}{l}640 \\
634\end{array}$ & $\begin{array}{l}600 \\
600\end{array}$ \\
\hline N.S. & $\begin{array}{l}\text { Control } \\
\text { APH }\end{array}$ & $\begin{array}{l}68 \\
70\end{array}$ & $\begin{array}{l}70 \\
39\end{array}$ & $\begin{array}{l}517 \\
517\end{array}$ & $\begin{array}{l}505 \\
490\end{array}$ \\
\hline G.N. & $\begin{array}{l}\text { Control } \\
\text { APH }\end{array}$ & $\begin{array}{l}68 \\
70\end{array}$ & $\begin{array}{l}68 \\
41\end{array}$ & $\begin{array}{l}714 \\
693\end{array}$ & $\begin{array}{l}638 \\
688\end{array}$ \\
\hline \multicolumn{6}{|c|}{ G6PD-deficient } \\
\hline L.G. & $\begin{array}{l}\text { Control } \\
\text { APH }\end{array}$ & $\begin{array}{l}42 \\
39\end{array}$ & $\begin{array}{r}42 \\
1\end{array}$ & $\begin{array}{l}513 \\
494\end{array}$ & $\begin{array}{l}494 \\
486\end{array}$ \\
\hline A.M. & $\begin{array}{l}\text { Control } \\
\text { APH }\end{array}$ & $\begin{array}{l}64 \\
62\end{array}$ & $\begin{array}{r}55 \\
0\end{array}$ & $\begin{array}{l}750 \\
800\end{array}$ & $\begin{array}{l}843 \\
824\end{array}$ \\
\hline J.H. & $\begin{array}{l}\text { Control } \\
\text { APH }\end{array}$ & $\begin{array}{l}56 \\
56\end{array}$ & $\begin{array}{r}52 \\
2\end{array}$ & $\begin{array}{l}506 \\
510\end{array}$ & $\begin{array}{l}552 \\
559\end{array}$ \\
\hline P.J. & $\begin{array}{l}\text { Control } \\
\text { APH }\end{array}$ & $\begin{array}{l}49 \\
51\end{array}$ & $\begin{array}{r}51 \\
4\end{array}$ & $\begin{array}{l}697 \\
674\end{array}$ & $\begin{array}{l}645 \\
670\end{array}$ \\
\hline
\end{tabular}

ditions of incubation in which about $50 \%$ of the initial GSH remained in the normal erythrocytes, whereas no appreciable GSH remained in the G6PD-deficient cells. LA was not oxidized when incubated in phosphate buffer with $\mathrm{APH}$ at $37^{\circ} \mathrm{C}$.

The data in Table II indicate that reincubation of cells with glucose, after preincubation with $\mathrm{APH}$, leads to a greater diminution in the utilization of glucose by G6PD-deficient cells than by normal erythrocytes. The finding of a marked decrease in glucose utilization in G6PD-deficient erythrocytes treated with APH is consistent with the alterations in LA and PA production that were observed.

In trying to elucidate the mechanism by which these effects were produced by APH in normal and in G6PD-deficient cells, we investigated the activity of some of the enzymes of the glycolytic pathway.

It has been suggested that a decline in GSH in the erythrocyte might inactivate or render more vulnerable to destruction those enzymes that appear to be dependent on sulfhydryl groups for their activity. A likely example of such an enzyme appeared to be GA3PD; GSH in bound form has been reported to be a constituent of this enzyme (16). The activity of the enzyme was 
studied in normal and in G6PD-deficient erythrocytes at the beginning and after $7 \frac{1}{2}$ hours of incubation in the absence and in the presence of added APH (Table III). Under these conditions the GSH of the G6PD-deficient cells declined to essentially zero levels within $2 \frac{1}{2}$ to 5 hours of incubation with APH, while the GSH of normal cells fell no more than to levels of 32 to $41 \mathrm{mg}$ per $100 \mathrm{ml}$ erythrocytes after $7 \frac{1}{2}$ hours of incubation. Despite the virtual elimination of GSH from the G6PD-deficient erythrocytes, the activity of GA3PD remained essentially unchanged. The diminished glycolysis which was observed in the G6PD-deficient erythrocytes treated with APH cannot be ascribed, therefore, to a diminution in the activity of this enzyme.

$L D H$ activity and DPNH. The accumulation of PA in normal erythrocytes and its significantly greater accumulation in G6PD-deficient erythrocytes treated with APH suggested the possibility of diminished activity of LDH. Studies of the activity of this enzyme in normal and in G6PD-deficient cells at the beginning of incubation and after 5 and $7 \frac{1}{2}$ hours in the absence and presence of added $\mathrm{APH}$ revealed no change in $\mathrm{LDH}$ activity that could account for the observed accumulation of PA (Table IV). These results suggest that there might be a deficiency of the coenzyme

TABLE IV

Effect of incubation with acetylphenylhydrazine $(A P H)$ on lactic dehydrogenase activity* in normal and glucose-6phosphate dehydrogenase (G6PD)-deficient erythrocytes

\begin{tabular}{|c|c|c|c|c|}
\hline Subject & & $0 \mathrm{hr}$ & $5 \mathrm{hrs}$ & $7 \frac{1}{2} \mathrm{hrs}$ \\
\hline \multicolumn{5}{|l|}{ Normal } \\
\hline N.S. & $\begin{array}{l}\text { Control } \\
\text { APH }\end{array}$ & $\begin{array}{l}440 \\
453\end{array}$ & $\begin{array}{l}470 \\
386\end{array}$ & \\
\hline E.G. & $\begin{array}{l}\text { Control } \\
\text { APH }\end{array}$ & $\begin{array}{l}613 \\
720\end{array}$ & $\begin{array}{l}630 \text { (6 hrs) } \\
590 \text { (6 hrs) }\end{array}$ & \\
\hline E.J. & $\begin{array}{l}\text { Control } \\
\text { APH }\end{array}$ & $\begin{array}{l}678 \\
672\end{array}$ & $\begin{array}{l}794 \\
800\end{array}$ & $\begin{array}{l}810 \\
720\end{array}$ \\
\hline G.V. & $\begin{array}{l}\text { Control } \\
\text { APH }\end{array}$ & $\begin{array}{l}530 \\
573\end{array}$ & $\begin{array}{l}609 \\
503\end{array}$ & $\begin{array}{l}590 \\
481\end{array}$ \\
\hline B.L. & $\begin{array}{l}\text { Control } \\
\text { APH }\end{array}$ & $\begin{array}{l}540 \\
507\end{array}$ & $\begin{array}{l}510(6 \mathrm{hrs}) \\
462(6 \mathrm{hrs})\end{array}$ & \\
\hline \multicolumn{5}{|c|}{ G6PD-deficient } \\
\hline A.M. & $\begin{array}{l}\text { Control } \\
\text { APH }\end{array}$ & $\begin{array}{l}987 \\
987\end{array}$ & $\begin{array}{r}1,097 \text { (6 hrs) } \\
962(6 \mathrm{hrs})\end{array}$ & \\
\hline A.M. & $\begin{array}{l}\text { Control } \\
\text { APH }\end{array}$ & $\begin{array}{r}976 \\
1,000\end{array}$ & $\begin{array}{r}1,130 \\
936\end{array}$ & $\begin{array}{r}1,176 \\
968\end{array}$ \\
\hline L.G. & $\begin{array}{l}\text { Control } \\
\text { APH }\end{array}$ & $\begin{array}{l}596 \\
599\end{array}$ & $\begin{array}{l}669 \\
544\end{array}$ & $\begin{array}{l}639 \\
508\end{array}$ \\
\hline P.J. & $\begin{array}{l}\text { Control } \\
\text { APH }\end{array}$ & $\begin{array}{l}619 \\
611\end{array}$ & $\begin{array}{l}725 \\
596\end{array}$ & $\begin{array}{l}664 \\
513\end{array}$ \\
\hline
\end{tabular}

* Optical density, units per minute per gram of hemoglobin at 340
TABLE $\mathrm{V}$

Effect of acetylphenylhydrazine $(A P H)$ on DPNH at $37^{\circ} \mathrm{C}$ in 30 minutes*

\begin{tabular}{|c|c|c|c|}
\hline & DPNH & $\begin{array}{l}\text { DPNH } \\
+\mathrm{APH}\end{array}$ & $\begin{array}{l}\text { DPNH } \\
+\mathrm{APH} \\
+\mathrm{GSH}\end{array}$ \\
\hline With lysate & .007 & .064 & .018 \\
\hline Without lysate & .007 & .039 & .009 \\
\hline
\end{tabular}

* Decrease in optical density at $340 \mathrm{~m} \mu$. DPNH, $100 \mu \mathrm{g} / \mathrm{ml} ; \mathrm{APH}$, $1 \mathrm{mg} / \mathrm{ml}$; GSH, $200 \mu \mathrm{g} / \mathrm{ml}$; lysate, $275 \mu \mathrm{g}$ of hemoglobin $/ \mathrm{ml}$; phosphate $1 \mathrm{mg} / \mathrm{ml} ; \mathrm{GSH}, 200 \mu \mathrm{g} / \mathrm{ml}$; lysate
buffer, pH 7.2, $4.4 \times 10^{-2} \mathrm{M}$.

$\mathrm{DPNH}$ in the APH-treated cells. Indeed, it was found that more added $\mathrm{DPNH}$ was required to convert a given amount of added PA to LA in lysates made of APH-treated cells than in the controls. This finding suggests a diminished availability of $\mathrm{DPNH}$ in the presence of $\mathrm{APH}$.

It was also found that the addition of APH to a solution of DPNH resulted in oxidation of the $\mathrm{DPNH}$, and that this oxidation could be prevented by the simultaneous addition of GSH. The oxidation of DPNH by APH was accelerated in the presence of a hemolysate, but the addition of GSH was nonetheless effective in protecting the DPNH. The data from a representative experiment are shown in Table $\mathrm{V}$.

\section{DISCUSSION}

In considering whether a diminution in the content of GSH in G6PD-deficient erythrocytes plays a causal role in the destruction of these cells, it is important to determine whether there are demonstrable differences in the metabolic activities of normal and G6PD-deficient erythrocytes under conditions in which the level of GSH is only partially diminished in the normal cells, but virtually eliminated in the G6PD-deficient cells.

A difference in glucose utilization between normal and G6PD-deficient erythrocytes was noted after preincubating the cells with $\mathrm{APH}$, removing the APH by washing, and reincubating the cells with glucose. Since present methods are not adequate for the measurement of glucose in the presence of APH (17), the actual utilization of glucose by erythrocytes in the continued presence of APH is uncertain. Glycolytic activity in the presence of $\mathrm{APH}$, however, could be evaluated by determining the formation of LA and PA. An accumulation of PA in both normal and G6PDdeficient erythrocytes occurred when they were 
treated with APH. But the effect of APH was much more pronounced in the deficient cells. The sum of LA and PA was not diminished in normal cells treated with APH, but was diminished in the G6PD-deficient cells. These results indicate that the glycolytic reactions by which ATP is regenerated are maintained in normal erythrocytes, but are reduced in deficient cells under the conditions of these experiments. These findings are consistent with the results of Löhr and Waller (18), who reported diminished levels of ATP in deficient erythrocytes treated with primaquine, but not in normal cells. Mohler and Williams (19) also observed a significant fall in ATP content of deficient cells in their studies with phenylhydrazine hydrochloride, although there was some fall also in normal cells.

This effect of APH could not be ascribed to altered activities of GA3PD and $\mathrm{LDH}$, since the activities of these enzymes were maintained despite a marked decline in free GSH. Although the measurement of enzyme activity in a lysate may not reflect exactly the activity of that enzyme within the intact cell, the observed activities of $\mathrm{LDH}$ and GA3PD were hundreds of times greater than would be required for the formation of the amounts of LA found. In the absence of a marked decrease in the measured activities of these enzymes, it would appear highly unlikely that the activities of these enzymes are rate limiting in the erythrocytes treated with $\mathrm{APH}$. The maintenance of the activities of GA3PD and LDH in APHtreated cells is in agreement with the observations of Löhr and Waller in primaquine-treated cells (18), but is at variance with the reported findings of Scheuch and Rapoport in erythrocytes treated with phenylhydrazine hydrochloride (20). The latter described a marked decline in the activity of GA3PD after incubating rabbit erythrocytes with phenylhydrazine hydrochloride and concluded that the stability of GA3PD is closely tied to the presence of free GSH. However, no data were presented on the content of GSH in the mature rabbit erythrocytes before and after treatment with phenylhydrazine hydrochloride, and the activity of the enzyme immediately upon the addition of phenylhydrazine hydrochloride is also not described. On adding phenylhydrazine hydrochloride to rabbit erythrocytes in the same con- centration they used, we have observed immediate denaturation of hemoglobin. This instantaneous effect was also observed by Jandl, Engle, and Allen (21) in their studies on human hemoglobin. It is probable that phenylhydrazine hydrochloride is directly injurious to cell constituents, including protein enzymes. Phenylhydrazine hydrochloride can oxidize GSH, but it does not follow necessarily that a decline in GSH must be attended by an immediate decline in the activity of GA3PD. The examination of this question requires conditions such as those that obtain in G6PD-deficient cells in which enzymatic activities can be studied in the virtual absence of free GSH.

The accumulation of PA might be due to an inadequate supply of DPNH. This possibility is supported by the finding of a decrease in DPNH when APH is added to a solution of DPNH with, and without, added hemolysate. GSH appears to prevent DPNH destruction by APH. The mechanism by which GSH protects DPNH under these conditions deserves further study.

The recent studies of Eldjarn and Bremer (22) may be pertinent to the findings reported here. On treatment of normal human erythrocytes with disulfides, they have found that the utilization of glucose by the erythrocytes is inhibited, but that the utilization of inosine or adenosine is unimpaired. They suggest, therefore, that the inhibitory effect of the disulfides is exercised at the hexokinase level, whereas other $\mathrm{SH}$ enzymes such as GA3PD seem to be unaffected.

The hypothesis that the diminution in glycolysis in erythrocytes depleted of GSH is a function of their hexokinase activity is currently under investigation.

\section{SUMMARY}

Studies on glucose-6-phosphate dehydrogenasedeficient erythrocytes reveal diminished glycolytic activity when the cells are depleted of their GSH by treatment with acetylphenylhydrazine (APH). Under these conditions no alteration occurs in the activity of glyceraldehyde-3-phosphate dehydrogenase and lactic dehydrogenase. This study indicates a possible role of GSH in preventing the oxidation of $\mathrm{DPNH}$ in the presence of agents such as APH. 


\section{REFERENCES}

1. Sternschuss, N., G. A. Vanderhoff, E. R. Jaffé, and I. M. London. Metabolic changes in normal and glucose-6-phosphate dehydrogenase-deficient erythrocytes induced by acetylphenylhydrazine (abstract). J. clin. Invest. 1961, 40, 1083.

2. Tarlov, A. R., G. J. Brewer, P. E. Carson, and A. S. Alving. Primaquine sensitivity. Glucose-6-phosphate dehydrogenase deficiency: an inborn error of metabolism of medical and biological significance. Arch. intern. Med. 1962, 109, 209.

3. Dern, R. J., I. M. Weinstein, G. V. LeRoy, D. W. Talmage, and A. S. Alving. The hemolytic effect of primaquine. I. The localization of the druginduced hemolytic defect in primaquine-sensitive individuals. J. Lab. clin. Med. 1954, 43, 303.

4. Brewer, G. J., A. R. Tarlov, and R. W. Kellermeyer. The hemolytic effect of primaquine. XII. Shortened erythrocyte life span in primaquine-sensitive male Negroes in the absence of drug administration. J. Lab. clin. Med. 1961, 58, 217.

5. Carson, P. E., C. L. Flanagan, C. E. Ickes, and A. S. Alving. Enzymatic deficiency in primaquinesensitive erythrocytes. Science 1956, 124, 484.

6. Flanagan, C. L., S. L. Schrier, P. E. Carson, and A. S. Alving. The hemolytic effect of primaquine. VIII. The effect of drug administration on parameters of primaquine sensitivity. J. Lab. clin. Med. 1958, 51, 600.

7. Beutler, E. The glutathione instability of drugsensitive red cells. A new method for the in vitro detection of drug sensitivity. J. Lab. clin. Med. 1957, 49, 84.

8. Marks, P. A. Red cell glucose-6-phosphate and 6phosphogluconic dehydrogenases and nucleoside phosphorylase. Science 1958, 127, 1338.

9. Barker, S. B., and W. H. Summerson. The colorimetric determination of lactic acid in biological material. J. biol. Chem. 1941, 138, 535.

10. Friedemann, T. E., and G. E. Haugen. Pyruvic acid. II. The determination of keto acids in blood and urine. J. biol. Chem. 1943, 147, 415.
11. Nelson, N. A photometric adaptation of the Somogyi method for the determination of glucose. J. biol. Chem. 1944, 153, 375.

12. Wintrobe, M. M. Clinical Hematology. Philadelphia, Lea \& Febiger, 1961, p. 379.

13. Wu, R., and E. Racker. Regulatory mechanisms in carbohydrate metabolism: III. Limiting factors in glycolysis of ascites tumor cells. J. biol. Chem. 1959, 234, 1029.

14. Wróblewski, F., and J. S. LaDue. Lactic dehydrogenase activity in blood. Proc. Soc. exp. Biol. (N. Y.) 1955, 90, 210.

15. Crosby, W. H., J. L. Munn, and F. W. Furth. Standardizing a method for clinical hemoglobinometry. U. S. armed Forces med. J. 1954, 5, 693.

16. Krimsky, I., and E. Racker. Glutathione, a prosthetic group of glyceraldehyde-3-phosphate dehydrogenase. J. biol. Chem. 1952, 198, 721.

17. Szeinberg, A., and P. A. Marks. Substances stimulating glucose catabolism by the oxidative reactions of the pentose phosphate pathway in human erythrocytes. J. clin. Invest. 1961, 40, 914.

18. Löhr, G. W., and H. D. Waller. Biochemie und Pathogenese der enzymopenischen hämolytischen Anämien. Dtsch. med. Wschr. 1961, 86, 27, 87.

19. Mohler, D. N., and W. J. Williams. The effect of phenylhydrazine on the adenosine-triphosphate content of normal and glucose-6-phosphate dehydrogenase-deficient human blood. J. clin. Invest. 1961, 40, 1735.

20. Scheuch, D., and S. M. Rapoport. Glutathion and Triosephosphatdehydrogenase-Aktivität in roten Blutzellen von Kaninchen. Klin. Wschr. 1960, 38, 757.

21. Jandl, J. H., L. K. Engle, and D. W. Allen. Oxidative hemolysis and precipitation of hemoglobin. I. Heinz body anemias as an acceleration of red cell aging. J. clin. Invest. 1960, 39, 1818.

22. Eldjarn, L. and J. Bremer. The inhibitory effect at the hexokinase level of disulphides on glucose metabolism in human erythrocytes. Biochem. J. 1962, 84, 286. 